\title{
PAŃSTWOWA KOMISJA WYBORCZA W ROKU 1989
}

Znana wypowiedź Joanny Szczepkowskiej w państwowej telewizji, że w dniu 4 czerwca 1989 r. skończył się w Polsce komunizm, nie jest stwierdzeniem mającym pewne potwierdzenie w faktach. Oddaje jednak - moim zdaniem - trafnie nie tylko symboliczne znaczenie tamtej daty. Niewątpliwie tzw. strona rządowa, przystępując do rozmów Okragłego Stołu, wychodziła z założenia, że sama nie jest już $\mathrm{w}$ stanie ponosić odpowiedzialności za losy Polski i polskiego społeczeństwa. Okres po wprowadzeniu stanu wojennego, brak jakiegokolwiek postępu w uzdrawianiu katastrofalnej sytuacji gospodarczej, brak rozwiązania jakichkolwiek nabrzmiałych problemów społecznych, zniecierpliwienie przywódców ZSRR, dały do zrozumienia, w każdym razie niektórym, z ówczesnych władców Polski, że trzeba doprowadzić do kontrolowanych przez obóz komunistyczny zmian, a w szczególności wydawało się tej opcji politycznej konieczne podzielenie się odpowiedzialnością za dalszy bieg wypadków z opozycja, z przedstawicielami społeczeństwa nienależącymi do obozu władzy.

Strona społeczno-solidarnościowa dostrzegła w możliwym dialogu szansę na istotne, a nie tylko pozorowane zmiany, szansę na rozpoczęcie długoletniego procesu reformowania systemu. Stąd zgoda na porozumienie Okragłego Stołu, stąd zgoda na nie w pełni demokratyczne wybory 4 czerwca. Wybory te miały być w oczach rządzących potwierdzeniem ich linii dopuszczenia opozycji solidarnościowej do odpowiedzialności za państwo, tym samym zrzucenia części tej odpowiedzialności z barków władzy komunistycznej.

Wynik wyborów czerwcowych te założenia przekreślił. Klęska obozu rządzącego i triumf „Solidarności” uwidoczniony w wyniku wyborów do Senatu, które miały charakter demokratyczny i wolny, uczyniły niemożliwym kontynuowanie dalej powolnego, a może nawet w zamysłach niektórych - pozornego, procesu zmian. Po 4 czerwca dotychczasowa władza miała dwa wyjścia: zdecydowanie się na rozwiązanie siłowe oznaczające katastrofę narodowa, a może katastrofę w rozmiarach europejskich lub nawet globalnych, albo oddanie władzy. Na szczęście zwyciężył wtedy zdrowy rozsądek i dlatego 4 czerwca 1989 r. mógł przejść do historii Polski jako dzień świadczący o politycznej mądrości Polaków, jako dzień symbolizujący upadek komunizmu oraz politycznego zniewolenia trwającego od końca II wojny światowej.

Zgoda na nie w pełni demokratyczne wybory do Sejmu nie oznaczała zgody na dotychczasowe praktyki ustalania wyników głosowania daleko od urn wyborczych. O skali fałszerstw w poprzednich wyborach można się było przekonać 
na podstawie obserwacji lokali wyborczych 4 czerwca. Do lokali stały kolejki, widać było duże zainteresowanie wyborami, wręcz czasami entuzjazm. Jak się okazało, w wyborach czerwcowych wzięło udział nieco ponad $62 \%$ uprawnionych do głosowania. W wyborach przeprowadzanych poprzednio, gdy lokale wyborcze nie były wcale oblegane przez chętny do oddania głosów tłum, oficjalnie podawana frekwencja przekraczała $95 \%$, a poparcie dla tzw. wspólnej listy było jeszcze wyższe. Wybory z 4 czerwca 1989 r. miały być po raz pierwszy w okresie powojennym uczciwe. Miała to zagwarantować Państwowa Komisja Wyborczapierwszy organ państwowy utworzony w wyniku rozmów Okragłego Stołu, w którym reprezentowana miała być też opozycja.

$\mathrm{Na}$ zaproszenie profesora Adama Strzembosza brałem udział w rozmowach Okragłego Stołu w tzw. podstoliku prawniczym. Profesor Strzembosz był z ramienia „Solidarności” współprzewodniczącym tych rozmów. Sprawy wyborcze nie były przedmiotem rozmów naszego podstolika. Negocjowane były na wyższym szczeblu. Jako karnista nie miałem wielkiego pojęcia o prawie wyborczym, jeśli w ogóle w tamtych czasach o takiej dziedzinie prawa można było poważnie mówić. W naszej grupie było dwoje wybitnych konstytucjonalistów: profesor Janina Zakrzewska oraz wówczas docent Jerzy Ciemniewski. Im to zawdzięczam, że gdy powstał problem dobrania przedstawicieli opozycji do tworzonej Państwowej Komisji Wyborczej, znalazłem się w tym składzie, a nawet ku mojemu pełnemu zaskoczeniu - wskazano mnie na jednego z czterech wiceprzewodniczących PKW.

Państwowa Komisja Wyborcza została powołana na podstawie Ordynacji wyborczej z 7 kwietnia 1989 r. ${ }^{1}$ Przewodniczacego, od 2 do 4 zastępców, sekretarza i 15 członków powoływała Rada Państwa ${ }^{2}$. Uchwała Rady Państwa powołująca skład PKW nosi datę 13 kwietnia 1989 r., przewodniczącym PKW został wybitny specjalista prawa międzynarodowego, profesor Uniwersytetu im. Adama Mickiewicza w Poznaniu i ówczesny prezes Trybunału Konstytucyjnego - Alfons Klafkowski. Grupa wskazana przez „Solidarność”, powołana do PKW przez Radę Państwa liczyła 6 osób. Należeli do niej Piotr Andrzejewski, Jerzy Ciemniewski, Anatol Lawina, Zofia Wasilkowska, Janina Zakrzewska i ja. Liczebność naszej grupy odpowiadała ustaleniom przy Okragłym Stole 35\% reprezentacji opozycji. Skład PKW miał oczywiście charakter polityczny, co stawiało przed naszą mniejszościową grupą szczególne zadania.

Jeszcze przed pierwszym posiedzeniem PKW wyznaczonym na 20 kwietnia 1989 r. spotkaliśmy się w naszej solidarnościowej grupie dwukrotnie, aby omówić nasze zadania i strategię postępowania. Spotkania te miały miejsce w siedzibie warszawskiego KiK-u przy ulicy Kopernika oraz w mieszkaniu Piotra Andrzejewskiego przy Wilczej. Zdawaliśmy sobie sprawę, że skoro jesteśmy w mniejszości, musimy starać się nie dopuszczać do głosowania. Jak się później okazało, było to zadanie wykonalne, gdyż naszym sojusznikiem w dbałości o zabezpieczenie uczciwych wyborów okazał się przewodniczący PKW profesor Klafkowski. Zresztą także wyniki nielicznych głosowań nie były już tak jednoznaczne i pokazywały pęknięcia w obozie władzy.

${ }^{1}$ Dz. U. Nr 19, poz. 102.

2 Art. 33 i 34 Ordynacji wyborczej. 
Posiedzenie PKW 20 kwietnia zapoczątkowało wręczenie nam przez zastępcę przewodniczącego Rady Państwa Zenona Komendera aktów nominacyjnych $^{3}$. Po czym przeszliśmy do pracy merytorycznej i doszło od razu do istotnej konfrontacji o charakterze jednoznacznie politycznym. Tak jak często praktykowano w PRL w wypadku większych gremiów mających podejmować decyzje, w porządku dziennym posiedzenia PKW znalazł się projekt uchwały upoważniającej prezydium PKW do wykonywania niektórych zadań w imieniu całej Komisji. Nie mogliśmy się na to zgodzić. Rozpoczęła się ostra, długo trwająca wymiana zdań i ku naszemu zdziwieniu odnieśliśmy sukces. Projekt uchwały nie został przyjęty. W protokole tego posiedzenia znajduje się zapis: „W wyniku dyskusji, Komisja przyjęła ustalenie, że wszystkie sprawy merytoryczne należące do jej kompetencji będą rozpatrywane i rozstrzygane na posiedzeniach plenarnych". Taki wynik dyskusji był w dużym stopniu zasługa przewodniczącego PKW, który samego projektu uchwały nie poddał pod głosowanie, lecz podsumował korzystny dla reprezentowanego przez nas stanowiska przebieg dyskusji.

Na tym posiedzeniu odnieśliśmy również istotny sukces, i to udokumentowany wynikiem głosowania. Chodziło o istotny politycznie problem, czy kandydatura na posła lub senatora ma być potwierdzona podpisami wyborców zamieszkujacych dany okręg wyborczy, czy też niezależnie od miejsca ich zamieszkania. Dla organizacji politycznych o zasięgu ogólnopolskim korzystniejsze było uznanie, że miejsce zamieszkania nie odgrywa roli. Naszym zdaniem kandydat powinien mieć poparcie wyborców zamieszkujących okręg, z którego kandyduje. Wygraliśmy głosowanie w stosunku 11 do 6. Pięć osób z reprezentujacych obóz władzy poparło nasze stanowisko.

W czasie tego posiedzenia interweniowałem w imieniu naszej grupy w sprawie doboru członków okręgowych komisji wyborczych. W niektórych z nich nie przewidziano miejsc dla reprezentantów opozycji. Uzyskaliśmy wydanie komunikatu przez PKW, w którym podkreślono „potrzebę zapewnienia pluralistycznego charakteru komisji wyborczych, stosownie do układu sił w przyszłym Sejmie”. Ten układ sił był przecież już ustalony. Trzeba to oceniać z perspektywy ex ante, a nie z perspektywy dzisiejszej.

Wychodząc z posiedzenia, szedłem za członkiem PKW w randze generała. Rozmawiał z innym członkiem Komisji i podniesionym, wyrażajacym zdenerwowanie głosem stwierdził, że „przez tych solidaruchów musimy tu siedzieć po parę godzin. Poprzednio po kwadransie był koniec posiedzenia”. Otrzymałem dowód, że byliśmy na dobrej drodze.

Kolejne posiedzenie PKW odbyło się 4 maja4. Poświęcone zostało szczegółowemu omówieniu Wytycznych PKW w sprawie zasad i trybu pracy komisji wyborczych w przygotowaniu i przeprowadzeniu wyborów do Sejmu i Senatu PRL w dniu 4 czerwca 1989 r. Zgłoszono wiele technicznych poprawek do przygotowanego w Kancelarii Rady Państwa projektu wytycznych.

${ }^{3}$ Zob. protokół posiedzenia PKW z 20 kwietnia 1989 r. nr 1/89 (strona Kancelarii Prezydenta RP, Archiwum przełomu, 1033/6k. 1-38).

${ }^{4}$ Zob. protokół posiedzenia PKW z 4 maja 1989 r. nr 2/89 (strona Kancelarii Prezydenta RP, Archiwum Przełomu, 1033/7k. 1-27). 
Jedna ze zgłoszonych wówczas przez naszą grupę poprawek była niezwykle ważna dla zabezpieczenia uczciwości wyborów. Mieliśmy podstawy przypuszczać, że możliwość fałszerstw występuje w czasie przekazywania protokołów z wynikami wyborów z obwodowych do okręgowych komisji wyborczych oraz z okręgowych komisji do PKW. Do wytycznych wprowadzony został zapis, odnoszący się zarówno do obwodowych, jak i okręgowych komisji wyborczych, że „niezwłocznie po sporządzeniu i podpisaniu protokołów, komisja podaje wyniki do wiadomości publicznej”. W praktyce oznaczało to obowiązek wywieszenia protokołów na drzwiach prowadzących do lokalu zajmowanego przez komisję wyborczą. Protokół taki mógł być np. sfotografowany, co umożliwiałoby kontrolę treści protokołu otrzymanego przez komisję wyższego stopnia. Ten prosty zabieg znakomicie utrudnił możliwość sfałszowania wyborów. Stał się zresztą stałym elementem obowiązującego prawa wyborczego.

Przy opracowaniu Wytycznych kładliśmy też nacisk na to, aby osoby, które nie były zameldowane w danym okręgu wyborczym i nie były umieszczone na listach, w razie dopuszczenia ich do głosowania były uwidaczniane na odrębnych listach. Chodziło o to, aby można było łatwo zidentyfikować ewentualne manipulacje z wędrującymi wyborcami. Domagaliśmy się też (skutecznie), aby Wytyczne określały wyraźnie, kto może przebywać w lokalu wyborczym, i aby członkowie komisji obwodowych nosili identyfikatory. Dotyczyć to także miało mężów zaufania poszczególnych komitetów wyborczych.

Na posiedzeniu 4 maja omawiana była też skarga, którą przedłożył naszej grupie Krzysztof Król - członek kierownictwa Konfederacji Polski Niepodległej (KPN). Spotkaliśmy się z nim przed posiedzeniem w mieszkaniu Piotra Andrzejewskiego. Chodziło o interwencje służb bezpieczeństwa z Lublina przeciwko zebraniom wyborczym organizowanym przez to ugrupowanie polityczne. W czasie dyskusji nad przedstawiona przez nas skarga okazało się, jakie emocje, także wśród członków PKW, wywołuje KPN. Najbardziej przeciwko udziałowi KPN w wyborach protestowali nawet nie przedstawiciele PZPR, ale Stronnictwa Demokratycznego i PAX-u. Udało się, bez przesądzania udziału KPN w wyborach jako odrębnego komitetu wyborczego, wydać następującej treści oświadczenie: „Państwowa Komisja Wyborcza [...] stwierdza, że niedopuszczalne jest dyskryminowanie komitetów wyborczych istniejących w sposób przewidziany w ustawie »Prawo o stowarzyszeniach". PKW stwierdza, iż działalność komitetów wyborczych, polegająca na realizowaniu praw wyborczych zbiorowości obywateli przewidzianych w ordynacjach wyborczych do Sejmu i Senatu podlega ochronie prawa. Jednocześnie PKW przypomina, że w okresie od zarządzenia wyborów do ich ukończenia, zgromadzenia wyborców organizowane w celu zgłoszenia kandydatów na posłów i senatorów oraz zwoływane i odbywane w ramach kampanii wyborczej prowadzonej na rzecz kandydatów nie podlegaja przepisom ustawy z 29 marca 1962 r. o zgromadzeniach". Można zauważyć, że oświadczenie to jest już wydane w innym duchu, niż byliśmy do tego przyzwyczajeni w okresie poprzednim. Charakterystyczna jest pod tym względem „Notatka służbowa” z 24 kwietnia 1989 r., a więc zaledwie sprzed 10 dni od oświadczenia PKW, podpisana przez dyrektora Gabine- 
tu Prezesa Głównego Urzędu Kontroli Publikacji i Widowisk, w której zwraca uwagę na podleganie kontroli wstępnej wszystkich publikacji rozpowszechnianych w ramach kampanii wyborczej ${ }^{5}$.

Godny przypomnienia jest wniosek złożony na tym posiedzeniu przez członka PKW Wojciecha Obarskiego, wiceprzewodniczącego Ogólnopolskiego Porozumienia Związków Zawodowych, w którym domagał się, by dyskusji poddawać tylko skargi i protesty złożone do Komisji na piśmie i żeby każde stanowisko Komisji poddawać pod głosowanie. Wniosek ten nie został jednak przez przewodniczącego PKW uwzględniony.

Na kolejnym posiedzeniu - 9 maja 1989 r. ${ }^{6}$ PKW zajęła się rozpatrzeniem skarg dotyczących naruszania Ordynacji wyborczej (np. rozpędzenie przez Milicję Obywatelska zgromadzenia zbierającego podpisy na rzecz osoby majacej zamiar kandydować z ramienia KPN-u w Toruniu) oraz interpretacją przepisów Ordynacji dotyczącą uprawnień do zgłaszania kandydatów. Rozpatrzono także sposób reakcji PKW na informacje dotyczące napaści na lokale komitetów wyborczych „Solidarności”. Na posiedzeniu tym rozpatrzono także przygotowanie do wyborów w obwodach zamkniętych (jednostkach wojskowych). Dyskusja koncentrowała się na problemie zapewnienia dostępu do wyborców kandydatów reprezentujących różne komitety wyborcze. Dla naszej grupy było sprawą zasadniczą umożliwienie spotkania się z wyborcami w obwodach zamkniętych także kandydatów zgłaszanych przez Komitety Obywatelskie.

Zgodnie z naszym wnioskiem uzupełniono wytyczne o obowiązek umieszczenia w protokole informacji o ilości osób dopisanych do protokołu na podstawie zaświadczeń upoważniających do głosowania oraz podawania w protokole informacji o ilości wydanych kart do głosowania. Te wydawałoby się drobiazgowe kwestie miały na celu utrudnienie manipulacji wpływajacych na rzetelność ustalania wyników głosowania w obwodzie.

Praca Państwowej Komisji Wyborczej była rzeczywiście intensywna, gdyż kolejne posiedzenie odbyło się już 12 maja 1989 r. ${ }^{7}$ Na posiedzeniu tym doszło do przedstawienia przez przedstawiciela Rady Krajowej PRON kandydatów startujacych w wyborach z tzw. listy krajowej, a więc zgłaszanych, zgodnie z Ordynacją z 7 kwietnia 1989 r., w odrębnym trybie poza okręgami wyborczymi. Ilość osób kandydujących z listy krajowej określała Rada Państwa. Na liście tej nie mogło być więcej niż 10\% liczby posłów ${ }^{8}$. Rada Państwa określiła tę ilość na 35 osób. Tyle też znalazło się na liście krajowej zarejestrowanej 12 maja przez PKW.

W trakcie tego posiedzenia podjęto ważne decyzje dotyczące wyglądu kart do głosowania (domagaliśmy się zróżnicowania formatu kart zawierających listę krajową i kart do głosowania zawierających kandydatów z okręgu). Omó-

\footnotetext{
${ }_{5}$ Notatka ta znajduje się w Kancelarii Prezydenta RP w Archiwum Przełomu (1033/3k.1-2).

${ }^{6}$ Zob. protokół posiedzenia PKW z 9 maja 1989 r. nr 3/89 (strona Kancelarii Prezydenta. Archiwum Przełomu 1033/8k. 4-12).

7 Zob. protokół posiedzenia PKW z 12 maja 1989 r. nr 4/89 (strona Kancelarii Prezydenta. Archiwum Przełomu 1033/9k. 1-13).

8 Art. 9 ust. 2 ustawy z 7 kwietnia 1989 r.
} 
wiono też organizację i przebieg wyborów poza granicami kraju (konsulaty, polskie statki handlowe).

Istotnym problemem było określenie zakresu możliwości przebywania $\mathrm{w}$ lokalach wyborczych przedstawicieli mass mediów. Trzeba przypomnieć, że Ordynacja wyborcza z 7 kwietnia 1989 r. nie przewidywała tzw. ciszy wyborczej. Państwowa Komisja Wyborcza przyjęła jednak dyrektywę zakazująca przeprowadzania na terenie lokalu wyborczego jakichkolwiek wywiadów. Informacje o frekwencji wyborczej powinny być ograniczone do dwóch terminów, a więc godz. 12.00 i 18.00. Zakazano też przebywania przedstawicielom mediów w lokalach wyborczych po zakończeniu głosowania.

Ważnym problemem było uzgodnienie informacji dla wyborców dostępnej w lokalach wyborczych, odnoszącej się do warunków ważności oddanego głosu. Jak się okazało w dniu wyborów, ten punkt miał istotne znaczenie. Zajęto się także szczegółowymi kwestiami związanymi z zapewnieniem równych możliwości kontaktu wyborców z kandydatami w obwodach zamkniętych (jednostki wojskowe, obiekty MSW).

W dniu 15 maja PKW rozpatrzyła szereg odwołań od decyzji okręgowych i wojewódzkich komisji wyborczych w sprawie rejestracji kandydatów ${ }^{9}$. Charakterystyczny dla tamtych czasów problem powstał $\mathrm{w}$ związku z odmowa przez jedna z komisji zgody na umieszczanie na obwieszczeniu wyborczym przy nazwisku kandydata znaku przynależności do „Solidarności”. Państwowa Komisja Wyborcza uznała prawo kandydata do podania w obwieszczeniu takiej informacji.

Posiedzenie PKW 18 maja poświęcone zostało wyłącznie uchwaleniu wytycznych dotyczacych przekazywania informacji o przebiegu wyborów w dniach 4 i 18 czerwca. Ustalono ostatecznie treść i wzory informacji, które miały być dostępne dla wyborców w lokalu wyborczym.

Kolejne posiedzenie PKW odbyło się 26 maja 1989 r. ${ }^{10}$ Istotną decyzją było dokonanie zmiany poprzednio przyjętych wytycznych odnoszących się do przekazywania protokołów głosowania z komisji obwodowych do komisji okręgowych i wojewódzkich. Już poprzednio stwierdziłem, że na tym etapie mogło dochodzić do zamiany protokołów i nasze wysiłki były skierowane, aby tego typu nieuczciwość absolutnie wykluczyć. W dokonanej zmianie chodziło o maksymalne ograniczenie ogniw pośrednich, tzn. przekazywania protokołów w tzw. regionach. Ze względów komunikacyjnych nie można było takich sytuacji w ogóle wykluczyć. Konieczne było jednak szczegółowe określenie procedury przekazania protokołów: komu mogą być przekazane, i że mogli być obecni przy tym mężowie zaufania komitetów wyborczych. Wykluczono także możliwość otwierania zapieczętowanych kopert zawierających protokoły. Protokoły takie mogły zostać otwarte dopiero w lokalu okręgowej lub wojewódzkiej komisji wyborczej w obecności całego składu komisji i mężów zaufania.

${ }^{9}$ Zob. protokół posiedzenia PKW w dniu 15 maja 1989 r. nr 5/89 (strona Kancelarii Prezydenta. Archiwum Przełomu 1033/10k.2-13.

${ }^{10}$ Zob. protokół posiedzenia PKW w dniu 26 maja 1989 r. nr 7/89 (strona Kancelarii Prezydenta. Archiwum Przełomu 1033/11k.1-15. 
Państwowa Komisja Wyborcza rozpatrywała szereg odwołań od decyzji okręgowych i wojewódzkich komisji wyborczych. Problem powstał w wypadku kandydata, który domagał się umieszczenia przy swoim nazwisku nazwy „Stronnictwo Pracy”. Organizacja o tej nazwie nie była wówczas zalegalizowana. Ten sam problem mieli kandydaci domagający się umieszczenia przy swoim nazwisku jako przynależność organizacyjna „KPN”. Komisje okręgowe i wojewódzkie odmawiały rejestracji tych kandydatów. Udało się, po bardzo burzliwej dyskusji, przeforsować mój wniosek o zwrócenie się do I Prezesa Sąu Najwyższego o dokonanie wykładni, czy w wyborach kandydat ma prawo domagać się umieszczenia przy swoim nazwisku nazwy organizacji, która nie przeszła wymaganego wówczas procesu legalizacji. Interesujące było także odwołanie kandydatki, która domagała się umieszczenia przy swoim nazwisku określenia „niezależna”. Komisja okręgowa odmówiła rejestracji. Tę decyzję podtrzymała PKW z argumentacja że nie jest to, o czym stanowiła Ordynacja wyborcza, wskazanie opcji politycznej kandydata.

$\mathrm{W}$ trakcie tego posiedzenia przyjęto także sprawozdanie przedstawiciela MSZ o organizacji wyborów poza granicami państwa.

Posiedzenie PKW 1 czerwca 1989 r. ${ }^{11}$ rozpoczęło się ostrą konfrontacja stanowisk w sprawie oceny opublikowanej w „Gazecie Wyborczej” instrukcji Biura Komitetu Obywatelskiego „Solidarnośćc dla biur terenowych Komitetów Obywatelskich w sprawie ustalania przez te biura wyników wyborów celem dodatkowej weryfikacji rzetelności wyborów i ogłoszonych wyników. Patrząc z perspektywy tamtych dni, trudno się dziwić, że opozycja nie miała zaufania do działań organów oficjalnych, a więc także do komisji wyborczych wszelkich szczebli. Państwowa Komisja Wyborcza miała jednak argument, aby ostro sprzeciwić się praktyce zalecanej przez Komitet Obywatelski „Solidarność”. Podniesiono w specjalnym oświadczeniu, że „ogłoszenie nieoficjalnych wyników przed ich ogłoszeniem przez Państwową Komisję Wyborczą może podważyć zaufanie do pracy komisji wyborczych, pracujących w składach zapewniających kontrolę wszystkich stron biorących udział w wyborach”. Myślę, że instrukcja była rzeczywiście zredagowana niezręcznie i akcentowała brak zaufania w końcu też do organów, w których „Solidarnośćc miała swoich przedstawicieli. Można było to samo osiagnąć przez wskazanie raczej na potrzebę informowania wyborców w drodze prowadzonych badań sondażowych. Dzisiejsza praktyka z wieczorami wyborczymi pokazuje całkowitą normalność tego zjawiska, które wcale nie jest nakierowane na kontrolę organów wyborczych, do których - co jest niezwykłym sukcesem polskiej transformacji - Polacy mają zaufanie.

Reprezentując naszą grupę solidarnościowa, zwróciłem uwagę na wyjątkowo szkodliwa, gdyż dezinformującą wyborców, wypowiedź sędziego Sądu Najwyższego Zenona Marmaja w głównym wydaniu Dziennika Telewizyjnego 31 maja 1989 r. i następnie rozpowszechnioną w prasie komunikatem PAP-u. Sędzia Marmaj stwierdził, że przekreślenie całej karty wyborczej zawierajacej listę krajową powoduje nieważność oddanego głosu. Taka ocena nie była

11 Zob. protokół posiedzenia PKW w dniu 1 czerwca 1989 r. nr 8/89 (strona Kancelarii Prezydenta. Archiwum Przełomu 1033/13k.1-10). 
oparta na żadnej podstawie prawnej i była sprzeczna z Wytycznymi PKW. Domagałem się wyraźnego zajęcia stanowiska przez PKW i natychmiastowego ogłoszenia go w mediach. Państwowa Komisja Wyborcza wydała następujące oświadczenie: „Państwowa Komisja Wyborcza po zapoznaniu się z tekstem telewizyjnego wystapienia sędziego Sądu Najwyższego Zenona Marmaja oraz komunikatu PAP-u z dnia 31 maja br. wyraża swoje głębokie ubolewanie z powodu zawartej w nich dezinformacji i lekceważenia ustaleń PKW odnośnie interpretacji art. 71 ust. 1 Ordynacji wyborczej. Zgodnie z Wytycznymi PKW z dnia 4 maja br., sposób skreślenia nie wpływa na ważność oddanego głosu, jeżeli wyborca jednocześnie wyraził swoją wolę co do wszystkich umieszczonych na karcie kandydatów".

Wykorzystanie osoby sędziego SN do akcji dezinformacyjnej, której celem było ratowanie listy krajowej, było sygnałem, że obóz władzy zaczyna mieć wątpliwości co do wyników wyborów. Trzeba stwierdzić, że przedstawiciele tego obozu byli bardzo pewni swojego sukcesu, skoro ustalono, że warunkiem wyboru z listy krajowej było otrzymanie ponad $50 \%$ ważnie oddanych głosów ${ }^{12}$. Nie przewidziano także, w odróżnieniu od pozostałych mandatów, drugiej tury wyborów w wypadku nieuzyskania przez któregokolwiek z kandydatów na liście krajowej wymaganej ilości głosów.

Posiedzenie 1 czerwca 1989 r. było ostatnim przed dniem wyborów. Członkowie Państwowej Komisji Wyborczej pełnili w dniu wyborów oraz w nocy z 4 na 5 czerwca dyżury. Pełniłem mój dyżur w budynku Sejmu, w gabinecie któregoś z członków Rady Państwa. Miałem bardzo dużo telefonów dotyczących ważności głosu po skreśleniu całej listy krajowej. Pytania dotyczyły, czy ważne są głosy, gdy lista zostanie przekreślona dwoma krzyżującymi się liniami i np. nazwisko kandydata na początku listy i na jej końcu nie zostanie przekreślone. Odpowiadałem, tak jak ustaliła to PKW, że takie skreślenie jednoznacznie wskazuje na wolę głosującego nieoddawania głosu na żadnego z kandydatów umieszczonych na liście krajowej. Były też wątpliwości dotyczące ważności takich głosów. Akcja sędziego Marmaja przyniosła owoce w każdym razie przez wprowadzenie w składach komisji wyborczych niepewności co do interpretacji prawa.

Po nieprzespanej nocy wyszedłem na spacer po Warszawie. Doszedłem do placu Konstytucji, gdzie mieściła się kawiarnia „Niespodzianka” będąca w owych dniach siedziba „Solidarności”. Przed kawiarnia tłum czekał na informacje o wynikach wyborów, choćby tych jeszcze nieoficjalnych. Zostałem rozpoznany, gdyż w dniach poprzedzajacych wybory kilka razy występowałem w telewizji. Ludzie mnie otoczyli i pytali o możliwość sfałszowania wyborów. Poczułem wtedy na sobie wręcz fizycznie ciężar odpowiedzialności za uczciwość wyborów. Po południu, gdy były już znane wyniki, odwiedziłem siedzibę „Solidarności” przy ulicy Fredry i tam byłem świadkiem telefonicznej rozmowy Bronisława Geremka z Lechem Wałęsa. Z rozmowy tej wynikała wielka troska związana z koniecznością wzięcia nie tylko cząstki, jak chciały władze,

12 Zob. art. 81 ust. 2 Ordynacji wyborczej. 
ale całości odpowiedzialności za Polskę. Zdawaliśmy sobie sprawę, że wynik wyborów ma przełomowe znaczenie historyczne. Przyszłość była dalej w wysokim stopniu niepewna. Przede wszystkim powstał problem z lista krajowa. Z listy tej tylko dwie osoby: Mikołaj Kozakiewicz i Adam Zieliński otrzymały wymaganą liczbę głosów i zdobyły mandat. Pozostali kandydaci w liczbie 33 nie zostali wybrani i brak było w Ordynacji wyborczej podstawy do przeprowadzenia wyborów odnośnie do tych mandatów.

Zostałem zaproszony na posiedzenie czołowych działaczy „Solidarności” (byli obecni m.in.: Lech Wałęsa, Tadeusz Mazowiecki, Bronisław Geremek, Jacek Ambroziak, Adam Michnik). Posiedzenie odbywało się w siedzibie Episkopatu przy dzisiejszym skwerze Kardynała Wyszyńskiego. Przedmiotem narady było wypracowanie stanowiska obozu solidarnościowego w sprawie wyborów uzupełniajacych w odniesieniu do listy krajowej. Miałem przedstawić stan prawny. Byłem w sytuacji praktycznie beznadziejnej, gdyż nie było żadnej podstawy prawnej do przeprowadzenia wyborów uzupełniających w zakresie mandatów, które miały być obsadzone z listy krajowej. Uznałem jednak wyraźnie, że nie będzie można, tak jak wielu obecnych chciało, dokonać uzupełnienia tych mandatów na podstawie nowej ustawy uchwalonej przez wybrane Sejm i Senat. Problem polegał na tym, że Sejm ma liczyć 460 posłów. Tylu nie zostało wybranych i nie byłoby - według tej koncepcji - wybranych w drugiej turze wyborów 18 czerwca 1989 r. Ostrzegłem, że może to być dobry pretekst do unieważnienia wyborów. Wielu związanych z obozem władzy czekało wtedy na pretekst, aby zakwestionować wyniki wyborów oznaczające klęskę obozu komunistycznego. Zaimponował mi wtedy Lecz Wałęsa swoim rozsądkiem i troską o bezpieczeństwo wewnętrzne. Po dyskusji to praktycznie on zdecydował, że należy się zgodzić, żeby obóz rządzący zgłosił w drugiej turze nowych kandydatów w miejsce tych, którzy odpadli z listy krajowej. Wymagało to nowelizacji Ordynacji wyborczej w trakcie trwających wyborów. Takiej konstrukcji prawnej nie wytrzymał konstytucjonalista Jerzy Ciemniewski i podał się do dymisji z funkcji członka PKW. Pozostała nasza piątka złożyła oświadczenie, że nie powinno się zmieniać reguł w trakcie trwających wyborów. Naszym zdaniem jednak nie było wtedy lepszego wyjścia z powstałej sytuacji.

Rada Państwa dekretem z 12 czerwca 1989 r. znowelizowała Ordynację wyborcza ${ }^{13} \mathrm{w}$ sposób umożliwiajacy zgłoszenie nowych kandydatów i przeprowadzenie wyborów uzupełniających już nie przez głosowanie na listę krajowa, lecz w okręgach wyborczych. Zgodnie ze stanowiskiem opozycji solidarnościowej kandydatów na te nieobsadzone mandaty zgłaszała tylko strona rządowa.

Ostatnie posiedzenie PKW w związku z wyborami czerwcowymi miało miejsce 20 czerwca 1989 r. ${ }^{14}$ Posiedzenie było poświęcone zatwierdzeniu wyników wyborów z 18 czerwca i przygotowaniu ich urzędowego obwieszczenia, a także przygotowaniu sprawozdania z przebiegu wyborów. Trzeba pamiętać,

${ }^{13}$ Zob. dekret Rady Państwa z 12 czerwca 1989 r. o zmianie ustawy - Ordynacja wyborcza do Sejmu Polskiej Rzeczypospolitej Ludowej X kadencji na lata 1989-1993 (Dz. U. Nr 36, poz. 198).

${ }_{14}$ Zob. protokół posiedzenia PKW w dniu 20 czerwca 1989 r. nr 12/89 (strona Kancelarii Prezydenta. Archiwum Przełomu 1033/15k.1-6). 
że obowiązywała wówczas zasada, iż ważność wyborów do Sejmu i Senatu stwierdzały te izby parlamentu ${ }^{15}$.

Razem z profesor Janiną Zakrzewską wręczaliśmy wybranym posłom i senatorom kandydującym z rekomendacji Komitetu Obywatelskiego przy Lechu Wałęsie akt wyboru. Uroczystość miała miejsce na Uniwersytecie Warszawskim w Audytorium Maximum. Nie było wtedy atmosfery do zorganizowania jednej uroczystości wręczenia aktów wyboru wszystkim wybranym parlamentarzystom. Odebrałem to jako źle wróżący sygnał o możliwości dobrej współpracy. Na szczęście myliłem się, gdyż Sejm X kadencji okazał się dobrze pracujacym na rzecz reformy państwa i tworzył dobre fundamenty pod budowę demokratycznego państwa prawnego.

Kadencja Państwowej Komisji Wyborczej trwała nadal, gdyż była związana z kadencją Sejmu i Senatu. Po rezygnacji z przewodniczenia PKW profesora Alfonsa Klafkowskiego zostałem powołany do pełnienia tej funkcji we wrześniu 1990 r. przez prezydenta Wojciecha Jaruzelskiego. Państwowa Komisja Wyborcza wybrana na kadencję 1989-1993 już się jednak nie zebrała. Nie było do tego powodu wynikającego z Ordynacji wyborczej.

Muszę to przypomnienie działalności PKW w wyborach czerwcowych zakończyć stwierdzeniem, że nasza grupa solidarnościowa miała wielką satysfakcję z tego, że udało się zabezpieczyć uczciwość tych wyborów. W ten sposób wydaje się, że wykonaliśmy dobrze powierzone nam zadanie.

prof. dr hab. Andrzej Zoll

Wyższa Szkoła Prawa i Administracji w Rzeszowie

em. profesor Uniwersytetu Jagiellońskiego

a.zoll@uj.edu.pl

THE STATE ELECTION COMMISSION IN 1989

Summary

It might be argued that the election of 4 June 1989 was of essential importance for the future of Poland. The agreement reached at the 'Round Table' merely provided for the presence of democratic opposition in Parliament, allowing it to exercise some control of the apparatus of power. The intention of that concession was to pass onto the opposition a share of responsibility for the state. However, as a result of the election that followed, the ruling communists had to actually hand down power to their opponents. This paper describes the efforts that the Citizens' Committee in the State Election Commission made to protect the integrity of the election. It also describes the process of electoral law formation in Poland, as well as the development of the legal culture of society.

${ }^{15}$ Dopiero od 1993 r. ważność wyborów parlamentarnych stwierdza swoim orzeczeniem Sąd Najwyższy. 
Copyright of Journal of Law, Economics and Sociology is the property of Faculty of Law and Administration of Adam Mickiewicz University in Poznan and its content may not be copied or emailed to multiple sites or posted to a listserv without the copyright holder's express written permission. However, users may print, download, or email articles for individual use.

Właścicielem praw autorskich do „Ruchu Prawniczego, Ekonomicznego i Socjologicznego” jest Wydział Prawa i Administracji Uniwersytetu im. Adama Mickiewicza w Poznaniu. Zawartość czasopisma nie może być kopiowana, przesyłana do innych stron internetowych bądź zamieszczana na blogach bez pisemnej zgody wydawcy. Niemniej artykuły można drukować, kopiować lub przesyłać w formie elektronicznej na własny użytek. 